\title{
PERANAN ASANA DALAM ANATOMI SISTEMATIK
}

\author{
Oleh:
}

\author{
I Gede Pasek Mancapara \\ Dosen Universitas Udayana
}

\begin{abstract}
:
Psychic and physical health become a desire for everyone, it is not only in health side, desire to have proportional body gesture, strong, and charismatic are the most things that human want to have. The scientists are competing to discover the solution including the eastern scientists with their oriental characteristic. The realization of such proportional body gesture is one of the goals from systematic anatomy as a part of the body that organized by the systems and functions. Based on the structural functionalism theory by Robert Merton, in the third part of the theory (indispensability) describe that all of the aspect of human body beside the positive side however it needs for the realization of the unity inside human body with the maximal function so it brings up psychic health or physical, including proportional body gesture and to realize something that can be studied in asana philosophy. Yoga philosophy has instructions to realize physic and physical health for locomotor system, digestive system, respiratory system, nervous system, and five senses that are part of systematic anatomy. Asana as the one of Yoga principal forms has a role in systematic anatomy, especially locomotor anatomy as the parts concerned with gestures.
\end{abstract}

Keywords : Āsana, Systematic Anatomy.

ABSTRACT:

Kesehatan psikis dan fisik menjadi keinginan semua orang. Tidak hanya dari sisi kesehatan saja, melainkan juga menginginkan postur tubuh yang ideal, kuat dan karismatik. Inilah hal yang diingikan manusia. Para saintis berlomba untuk mencari solusi termasuk saintis timur dengan karakter oriental. Realisasi dari badan yang proporsional adalah salah satu cita-cita dari anatomi sistematik sebagai bagian dari tubuh yang dikendalikan oleh system dan fungsi. Berdasarkan pada teori fungsional structural oleh Robert Merton, bagian ketiga dari teori tersebut menjelaskan bahwa seluruh aspek tubuh manusia disamping positifjuga memerlukan kesatuan di dalam tubuhnya dengan fungsi yang maksimal sehingga berpengaruh pada kesehatan psikis dan fisik, termasuk tubuh yang proporsional dan juga merealisasian sesuatu yang lain sebagaimana yang diajarkan di dalam filsafat asana. Filsafat Yoga menginstruksikan untuk merealisasikan kesehatan fisik dan psikis untuk system lokomotor, pencernaan, pernafasan, syaraf, dan kelima indera sebagai bagian dari anatomi tubuh. Asana sebagai salah satu prinsip dalam Yoga memiliki aturan di dalam anatomi sistematik, khususnya anatomi lokomotor sebagai bagian yang berhubungan langsung dengan gerak.

Kata Kunci: Asana, aatomi sistematik

\section{PENDAHULUAN}

Kesehatan psikis menjadi salah satu kesehatan yang didambakan orang-orang pada jaman sekarang ini, kerap kali seseorang mengalami tekanan dalam pikiran, mental, hingga mengakibatkan terjadinya depresi, alhasil efek sampingnya seperti susah tidur, sakit kepala, gelisah, temperamental dan hal lainnya yang berdampak buruk pada tubuh manusia/ fisik. Peristiwa tersebut sebagai salah satu penyakit dalam psikologi yang disebut psikosomatik yaitu penyakit kejiwa badanan, dalam artian penyakit yang ditimbulkan oleh psikis yang berdampak pada penyakit fisik. Disatu sisi teori yang dikemukakan Freud tentang psikoanalisis yang mengemukakan tentang fisik yang berdampak pada psikis hingga 
berdampak pada fisik kembali yang disebut sebut sebagai tekanan (repression) yang lebih dikenal sebagai tekanan batin. Hal ini menunjukkan bahwa psikis dan fisik saling berkaitan dan berhubungan. Sehingga untuk menjaga kesehatan fisik, hendaknya mewujudkan kesehatan psikis juga, demikian sebaliknya.

Seperti salah satu contohnya yang dikemukakan Sigmund Freud tentang neurosis (Neurotic), mengenai penyakit ganguan saraf yang mengakibatkan perilaku irrasional akibat dari uncosiuos mind (Pikiran bawah sadar). Menurut Freud angan-angan dan emosi turun dari pikiran sadar dan kemudian masuk ke alam bawah sadar dengan dua cara yaitu pertama mereka masuk dengan cara diam-diam dalam bentuk transkrip pengalaman masa lalu, atau kedua, transkrip pengalaman masa lalu itu dipaksa masuk karena sebab dan alasan-alasan tertentu, Freud menjelaskan bahwa angan-angan dan emosi itu dipaksa masuk oleh rasa tertekan (repression) yang dianggap telah terlupakan padahal sebenarnya belum hilang. Secara tidak sadar ia masih tertinggal di dalam pikiran dan berusaha untuk berfungsi kembali dengan cara yang amat rumit. Pikiran dan emosi orang yang tertekan dapat menjelma menjadi perilaku irrasional semisal gerakangerakan tanpa tujuan (persis orang mabuk), rasa takut yang tak berdasar, perasaan sayang yang tidak rasional, ritual-ritual obsesi pribadi dan perilakuperilaku aneh lainnya. Semua itu dideskripsikan Freud dalam istilah "Neurosis" (Neurotic). Ganguan saraf ini tidak bisa disembuhkan dengan pengobatan medis biasa, tapi hanya bisa ditolong dengan psiko analisis (Pals, 2012: 88).

Contoh diatas menunjukkan bagaimana analisa Freud tentang psikis yang berdampak pada fisik, demikian sebaliknya. Hal itu dikemukakan Freud bahwa pengalaman-pengalaman empiris yang dialami manusia yang menghasilkan suatu angan-angan dan emosi yang luar biasa dan diluar batas seseorang untuk memenuhi angan-angan dan emosi tersebut, sehingga mengalami proses repression, masuk ke-alam bawah sadar manusia, hingga mengalami tekanan batin yang nantinya berakibat menghasilkan perilaku yang irrasional (Fisik), selain psikosomatik, hal ini dalam istilah psikologi juga disebut sebagai somapsikotis yaitu gangguan fisik yang disebabkan oleh gangguan mental.

Mempunyai kesehatan fisik dan psikis merupakan salah satu bagian dari tujuan hidup manusia yaitu memperoleh kebahagiaan. Kebahagiaan bisa didapat jika kesehatan seutuhnya diperoleh dalam diri manusia, kesehatan seutuhnya yaitu kesehatan secara psikis dan fisik, untuk memperoleh hal tersebut salah satunya dengan mengharmoniskan dan menyeimbangkan, memfungsikan dengan optimal anatomi sistematik yang terdapat dalam diri manusia. Berbagai macam ilmu pengetahuan dikemukakan untuk memenuhi kebutuhan manusia untuk memperoleh kesehatan seutuhnya di dunia ini, tidak terkecuali ilmuan timur dengan ciri khas yang oriental.

Salah satunya dalam agama Hindu sendiri sebenarnya juga sudah terdapat ajaran tentang hal tersebut diatas, misalkan tentang kejiwa badanan seperti halnya teori psikoanalisa dan alam bawah sadar Sigmund Freud, dalam lontar Wrhasspati Tattwa terdapat kemiriban konsep tersebut yang disebut sebagai Cetana (Kesadaran)/ consciousness dan Acetana (Ketidak sadaran)/ unconsciousness (Mirsha dkk, 1994: ii).

Untuk mewujudkan gesture tubuh yang baik, kesehatan badan dan rohani, psikis dan fisik, ternyata juga sudah terdapat dalam ajaran agama Hindu bahkan dalam ruang lingkup satu ajaran saja yaitu melalui ajaran yoga. Tanpa harus melakukan terapi psikologis di dokter, tanpa melakukan olahraga keluar rumah, tanpa melakukan pelatihan model, agama Hindu memiliki ajaran tentang mewujudkan kesehatan psikis dan fisik tersebut dalam ajaran yoga, salah satunya melalui yogāngga bagian Āsana, dimana setiap prinsip-prinsip menjadi satu kesatuan yang terstruktur dan memiliki fungsinya, sehingga anatomi sistematik menjadi satu kesatuan yang utuh melalui pelaksanaan Yoga.

\section{PEMBAHASAN}

Peranan Āsana dalam Anatomi Sistematik

\section{Ajaran Āsana / Philosophy of Āsana}

Sebelum beralih ke tahap mengetahui 
peranan ataupun fungsi dari ajaran āsana terhadap anatomi sistematik, perlu kiranya dibahas secara terstruktur mengenai apa itu āsana dan apa itu anatomi sistematik, barulah kemudian ditemukan titik temu yang menyatakan fungsi dari ajaran $\bar{a}$ sana terhadap anatomi sistematik tersebut.

Āsana merupakan sikap badan yang mantap dan nyaman. Asana atau sikap badan merupakan bantuan secara fisik untuk konsentrasi. Bila seseorang berhasil memperoleh penguasaan terhadap āsana maka ia bebas dari ganguan pasangan-pasangan yang berlawanan (Sudirga dan Segara, 2014: 136). Selanjutnya dinyatakan oleh Donder dalam bukunya yang berjudul Brahmavidyā: Teologi Kasih Semesta (2006: 275) bahwa badan akan menjadi sehat, leluasa, dan mantap dengan melaksanakan āsana, bandha, mukti, dan mudra. Ásana berarti suatu keadaan tubuh dimana anda tetap mantap, tenang, santai, dan nyaman baik secara fisik maupun secara mental. Dalam tulisan kuno mengenai yoga oleh Patanjali yang disebut yogasutra, ada definisi singkat tentang yogāsana; Sthiram sukham āsanam yang berarti bahwa keadaan yang nyaman dan mantap (Sarasvatīi, 2002: 1).

Patanjali, seorang yogi, menerangkan bahwa yoga memiliki 8 bagian yang tidak terpisahkan, yaitu; Yama (Mengendalikan diri), Niyama (ketaatan), Asana (sikap badan), Pranayama (pengaturan nafas), Pratyahara (pengaturan diri/ indera), Dharana (Konsentrasi), Dhyana (Meditasi), dan Samadhi (Keseimbangan) (Maswinara dalam Gunawan, 2012: 142). Lebih jauh diterangkan bahwa Assana merupakan salah satu bagian dari prinsip Yoga dalam filsafat Yoga, prinsip-prinsip itu diantaranya :

a. Kelompok Pertama mempergunakan ; kesadaran, kesimpulan, dan kata (sabda). Pelaksanaan yoga adalah alat untuk mencapai perbedaan antara jiwa dan badan jasmani, pikiran dan pancaindera sebagai suatu kondisi penting untuk mencapai kelepasan. Orang harus memiliki nurani suci dan pikiran tenang, yoga adalah penyucian jiwa dari proses penyucian pikiran dan badan jasmani.

b. Kelompok kedua mempergunakan proses melalui; pengertian, kesadaran yang pengertian, kesadaran yang diperoleh dari persepsi, pengelihatan, kesimpulan dan ucapan yang diakui sebagai pengetahuan kebenaran = pramana . Pengertian, kesadaran yang salah atau palsu, termasuk kira-kira, keragu-raguan, dalih dan dugaan $=$ viparyaya . Pengertian, kesadaran yang didasarkan atas gagasan yang disampaikan secara lisan = vikalpa. Sikap mental yang dikuasai oleh kemalasan, rasa kantuk, dan masa bodo = nidra. Pengertian, kesadaran yang didasarkan atas ingatan pada pengalaman masa lampau. Dalam hal ini jiwa mengalami perubahan secara semu, berada di atas citta-vrtti, jiwa seperti kelihatan namun hanya merupakan refleksi, ibarat bayangan dalam cermin.

c. Kelompok ketiga adalah kondisi citta-verttinirodha, yaitu terhentinya proses modifikasi jiwa yang disebabkan oleh factor citta-bhumi, sebagai kondisi mental yang dipengaruhi oleh tiga jenis Tri Guna yaitu sattva, rajas, tamas (Pencerminan dari watak dan sifat baik-mulia, aktif-bernafsu, gelap-bodoh).

d. Kelompok keempat adalah cara dan alat untuk melaksanakan yoga yang praktis, yang disebut Yogāngga, yaitu; Yama yang merupakan pengekangan, ahimsa- tanpa kekerasan dan tidak membunuh, satya- benar dalam berkata dan pikiran, asetya- tidak mencuri, brahmacarya- sebagai santri tanpa melakukan hubungan seksual, aparigrahatanpa menerima hadiah yang tak perlu. Nyama berupa berkebudayaan, menumbuhkan kebiasaan-kebiasaan baik, sauca- penyucian badan jasmani dengan makanan yang halalsehat-bersih, pikiran yang sehat - bersih, benar - lurus, sentosa - puas akan seadanya, tapas - melakukan tapa brata, tahan panas dan dingin, hujan dan angin, siang dan malam, dan sebagainya melalui sumpah yang keras, svadhyaya - membiasakan belajar mendalami kitab-kitab suci, isvwarpranidhana-meditasi kepada Tuhan Yang Maha Esa. "Āsana” yang merupakan penjagaan kesehatan terhadap badan jasmani, menghasilkan badan yang teguh, kukuh, dan lega, dengan berbagai postur 
seperti padmasana - tegak lurus, virasana - perkasa sebagai pahlawan, bhadrasana - lega sebagai cendekiawan budiman dan sebagainya, dan juga postur lainnya. Pranayama; pengaturan pernfasan keluar, penuh, henti memperpanjang konsentrasi. Pratyahara; menarik pancaindera dari objekobjek pengelihatan, penciuman, pendengaran, perasaan, dan perabaan.

e. Sedangkan kelompok kelima termasuk petunjuk cara-cara melaksanakan Yoga, yang terdiri dari Dharana, Dhyana, dan Samadhi (Pendit, 2007: 111-117).

Melalui prinsip-prinsip yang terdapat dalam filsafat yoga tersebut diatas maka diketahui bahwa kedudukan Āsana merupakan salah satu bagian dari prinsip yoga darsana / filsafat yoga yang "keempat". Lebih lanjut dalam buku Āsana, pranayama, mudra, bandha dari Svāmī Satyānanda Sarasvatī (2002, 9-11) Āsana dikelompokkan menjadi kelompok-kelompok utama yang berbeda yaitu tingkatan pemula, tingkat menengah, dan tingkat tinggi. Kelompok pemula seharusnya dilakukan oleh orang-orang yang sebelumnya tidak pernah melakukan yogāsana, yang keadaannya lemah, atau sakit sehingga tidak mampu melakukan latihan-latihan yang sulit. Kelompok tingkatan menengah yang merupakan tingkatan āsana yang agak sulit untuk dilakukan bagi orang-orang yang dapat melakukan tingkat pemula tanpa ketidaknyamanan atau usaha yang paling ringan. Dalam asana ini diperlukan tigkat ketenangan, konsentrasi, dan korrdinasi dengan pernafasan yang lebih tinggi. Kelompok tingkatan ketiga yaitu kelompok tingkat tinggi, yang diperuntukkan bagi orang-orang yang memiliki keluasan tentang otot-otot dan susunan saraf, dan telah menguasai tingkat asana tingkat menengah.

Ásana juga dikelompokkan menjadi latihan dinamis dan statis. Latihan dinamis adalah āsana yang meliputi gerakan-gerakan tubuh yang penuh semangat. Sedangkan gerakan statis dilakukan dengan sedikit atau tanpa gerakan. Tubuh sering tetap pada satu posisi selama beberapa menit atau lebih (Sarasvatī, 2002: 10). Salah satu gerakan tersebut seperti contoh gambar berikut ini :
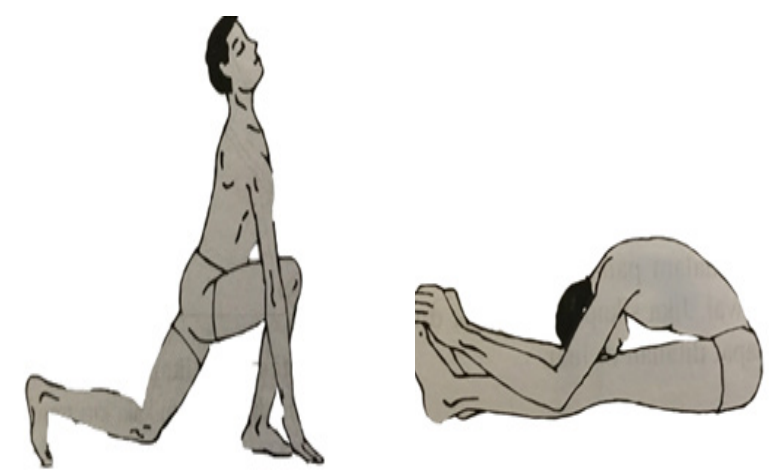

Sumber Photo : Sarasvatī, 2002: 137 Sumber Photo : Sarasvatī, 2002: 193

Gambar diatas menunjukkan bagaimana gerakan statis dan dinamis. Gerakan dinamis ditunjukkan dari gambar Aśva Sañcalanāsana yang dilaksanakan penuh semangat dan didahuli serta dilanjutkan dengan gerakan-gerakan sebelumnya dan berikutnya, sementara gerakan statis ditunjukkan oleh gambar Paścimottanāsana yang dilaksanakan dengan memperlambat kecepatan pernafasan. Kedua jenis pengelompokan tersebut tidak lain untuk kesehatan jasmani dan mental. Latihan gerakan yang dinamis sangat baik untuk kesehatan fisik, pergerakan tubuh yang dinamis menghasilkan pengoptimalan fungsi otot-otot, tulang, hingga sendi-sendi dan peredaran darah, sebaliknya āsana yang dilaksanakan sesuai tata cara kelompok statis, dipermaksudkan untuk memijat organ tubuh bagian dalam yang lembut, termasuk juga kelenjar dan otot-otot untuk mengendorkan saraf-saraf diseluruh tubuh. Melalui pengelompokan tersebut diatas sangat banyak lagi bagian-bagian yang berisikan masing-masing tahap gerakan tertentu, dari yang paling mudah untuk dilaksanakan hingga rumit sekalipun. Terlebih lagi bahwa ajaran āsana tidak membatasi usia untuk melaksanakannya baik wanita ataupun pria semasih tidak bertentangan dengan pembatasan-pembatasan yang dinyatakan dalam ajaran $\bar{a}$ sana tersebut.

\section{Anatomi Sistematik}

Anatomi Sistematik adalah pembagian tubuh dalam sistem-sistem yang disusun berdasarkan fungsinya (Pearce, 2017: 4). Salah satu goal yang menjadi tujuan setiap manusia adalah terwujudnya kebahagiaan, dan hal tersebut bisa didapatkan 
melalui kesehatan fisik dan mental/ psikis sehingga terwujud kebahagiaan yang absolut mengingat bahwa psikis dan fisik saling mempengaruhi. Kesehatan psikis dan fisik tersebut bisa diperoleh salah satunya jika masing-masing sistem susunan tubuh yang distrukturkan berdasarkan fungsinya dapat berfungsi dengan baik dan optimal.

Adapun bila dikelompokkan berdasarkan fungsinya, susunan umum sistem-sistem pada manusia tersebut dalam anatomi sistematik (Pearce, 2017: 4-5), sebagai berikut:

\section{a. Sistem Lokomotorik}

Sistem lokomotorik merupakan sistem yang mencakup bagian-bagian yang bersangkutan dengan gerak tubuh. Sistem kerangka mencakup tulang-tulang, tulang rawan, dan membrane tertentu. Sistem Artikulatorik berkenaan dengan sendi; sistem otot mencakup otot, fasia, dan tendon.

\section{b. Sistem Pembuluh Darah}

Sistem pembuluh darah mencakup sistem sirkulasi dan sistem saluran limfe. Darah merupakan sistem transfor yang utama. Darah dipompa mengintari tubuh oleh jantung, oksigen dibawa dari paru-paru, dan karbon dioksida dikumpulkan dari jaringan, makanan disalurkan melalui hati, dan kemudian masuk sirkulasi umum. Produk yang tidak diperlukan disalurkan ke ginjal.

\section{c. Sistem Pencernaan}

Sistem pencernaan terdiri atas saluran pencernaan beserta kelenjar dan organnya. Makanan dipecahkan enzim dalam saluran pencernaan, diangkut darah ke hati, dan akhirnya disalurkan ke jaringan.

\section{d. Sistem Pernapasan}

Sistem pernapasan terdiri dari saluran dan organ yang berhubungan dengan pernapasan. Oksigen dari udara diambil dan dimasukkan ke darah, kemudian diangkut ke jaringan. Produk yang tidak perlu, karbon dioksida (CO2), diangkut darah dari jaringan tubuh ke paru-paru dan dinapaskan keluar ke udara.

\section{e. Kelenjar Buntu}

Kelenjar Buntu dikelompokkan bersama karena sekresi yang dihasilkan disalurkan langsung ke darah atau organ pemakai. Ada kalanya limfe dimasukkan dalam kelompok ini sebab limfe juga tidak mempunyai saluran. Setahu kita kelenjar ini tidak menghasilkan sekresi, tetapi berkaitan dengan pembentukan sel darah merah.

\section{f. Sistem Urogenital}

Sistem Urogenital mencakup mencakup organ sistem urinari dan sistem reproduksi. Hasil buangan dari tubuh, kecuali karbon dioksida, diekskresikan ginjal.

\section{g. Sistem Saraf}

Sistem saraf terdiri atas susunan saraf pusat yang mencakup otak dan sumsum tulang belakang. Sistem saraf periferi atau susunan saraf tepi terdiri atas urat-urat saraf yang berasal dari otak dan sumsum tulang belakang, serta sistem saraf otonom. Sistem pusat dan periferi sering dikelompokkan bersama dan dilukiskan sebagai sistem saraf serebrospinal. Sistem saraf otonom mencakup saraf simpatik dan parasimpatik.

\section{h. Pancaindra}

Mencakup perasaan, penciuman, pengelihatan, pendengaran, dan perabaan (Pearce, 2017: 5). Dengan organ-organ ini manusia mampu melindungi diri dari ancaman-ancaman diluar dirinya, sehingga dapat menimbulkan kewaspadaan dan jaga-jaga terhadap kekuatan luar.

\section{i. Sistem Ekskretorik}

Sistem ini adalah istilah yang adakalanya dipakai untuk melukiskan secara kolektif organ yang berkenaan dengan ekskresi produk buangan tubuh. Demikian pembagian tubuh yang disusun dalam sistem-sitem berdasarkan fungsinya yang disebut dengan Anatomi sistematik. sistemsistem yang ada dalam tubuh itu dikelompokkan berdasarkan fungsinya yaitu ada sebagai sistem penggerak yang disebut sebagai sistem lokomotorik, sistem pembuluh darah yang merupakan sistem sirkulasi dan sistem saluran 
limfe, dimana darah memiliki peranan yang sangat penting dalam tubuh sebagai sistem transfor yang utama, kemudian terdapat juga sistem pencernaan, sistem pernafasan, kelenjar buntu, sistem urogenital, sistem saraf, panca indera, dan sistem ekskretorik.

\section{Peranan Āsana dalam Anatomi Sistematik}

Melalui pembahasan diatas maka jelas diketahui bahwa anatomi sistematik merupakan pembagian tubuh dalam sistem-sistem yang disusun berdasarkan fungsinya. sedangkan āsana merupakan sikap/keadaan badan yang nyaman dan mantap, asana merupakan sikap dalam ajaran yoga, tentang gerakan-gerakan tubuh yang tertuang dan sesuai dengan ajaran dalam āsana tersebut, āsana merupakan salah satu bagian prinsip dari yoga darsana/ filsafat yoga yang mampu memberikan kesehatan fisik dan psikis manusia.

Secara keseluruhan dan lebih mendalam, ajaran yoga merupakan ajaran yang mampu berfungsi dalam mewujudkan kesehatan baik psikis ataupun fisik termasuk juga didalamnya mem-fungsikan dengan optimal semua bagian yang terdapat dalam anatomi sistematik tersebut. Lebih khusnya lagi mengenai āsana sebagai salah satu bagian dari prinsip yoga dan berkaitan dengan teori fungsionalisme struktural Robert Merton. Walaupun teori fungsionalisme structural dari Merton merupakan teori tentang sosial, bisa diambil ideologi perihal kemiripannya dengan aspek-aspek yang ada pada tubuh manusia sebagai anatomi sistematik dengan aspek-aspek yang ada pada masyarakat yang sama sama esensinya saling berkaitan satu sama lain pada bagiannya masingmasing.

Jika dalam masyarakat, aspek-aspek tersebut dinyatakan oleh Merton saling mempengaruhi berfungsinya masyarakat sebagai suatu satu kesatuan, jika dalam tubuh manusia, semua aspek aspek anatomi sistematik saling mempengaruhi untuk berfungsinya tubuh manusia secara optimal dan terwujudnya kesehatan baik psikis ataupun fisik, karena fisik dan psikis saling berhubungan dan mempengaruhi.

Teori fungsionalisme structural dari Merton menyatakan bahwa fungsi didefinisikan sebagai konsekuensi-konsekuensi yang dapat diamati yang menimbulkan adaptasi atau penyesuaian dari sistem tertentu, lebih jauh dijelaskan dalam postulat ketiga dari teorinya (indispensability) yaitu semua aspek-aspek masyarakat yang sudah baku tidak hanya memiliki fungsi positif tetapi juga mencerminkan bagian-bagian yang sangat diperlukan bagi berfungsinya masyarakat sebagai satu kesatuan (Ritzer, 2015: 132).

Sesuai dengan teori fungsionalisme structural dari Merton, berkaitan dengan pembahasan disini, bisa diketahui bahwa āsana sebagai salah satu bagian dari kelompok prinsip ajaran yoga memiliki fungsi yang dapat diamati bagi manusia yang melaksanakannya, fungsi tersebut tidak lain adalah melalui āsana kesehatan fisik dan mental/ psikis dapat diperoleh seseorang dengan cara memfungsikan secara maksimal, meregangkan, melatih, menyeimbangkan secara simultan anatomi sistematis yang ada pada manusia melalui gerakan-gerakan yang ada pada ajaran āsana.

Masing-masing bagian dalam tubuh saling membutuhkan untuk mewujudkan kesehatan manusia yang utuh yaitu kesehatan fisik ataupun psikis, dan hal itu salah satunya bisa diperoleh dengan melaksanakan ajaran āsana. Hal ini berarti bahwa unsur-unsur yang ada pada ajaran āsana mewujudkan kesehatan yang utuh pada manusia dengan berfungsiny dengan optimal dan seimbang bagian-bagian anatomi sistematik. Disamping itu secara tidak langsung walaupun bukan merupakan tujuan utama dari ajaran āsana namun akan mengikuti pula terwujudnya gestur yang baik, tegap, dan lega, karena pergerakanpergerakan tubuh sedemikian rupa sesuai dengan ajaran āsana.

Meregangkan otot-otot yang lembut, memijat organ-organ tubuh bagian dalam, dan menyelaraskan urat syaraf diseluruh tubuh, kesehatan dari orang yang melakukan $\bar{a}$ sana dapat ditingkatkan, dan banyak penyakit bahkan apa yang disebut penyakit yang tak dapat disembuhkan dapat dilenyapkan atau dikurangi (Sarasvatī, 2002: 1-2). Yogāsana dilakukan secara pelanpelan dengan relaksasi dan konsentrasi. Dengan cara ini baik sistem eksternal maupun sistem internal akan terpengaruh hingga susunan syaraf, kelenjar-kelenjar endoktrin dan organ tubuh bagian dalam dan juga otot-otot didorong untuk 
berfungsi sebagaimana mestinya. Oleh karena itu āsana memiliki pengaruh fisik dan kejiwaan yang berguna dalam menyembuhkan berbagai penyakit (Sarasvatī, 2002: 3).

Pernyataan diatas menunjukkan bahwa pelaksanaan āsana dilakukan secara pelanpelan dengan relaksasi dan konsentrasi sehingga tidak saja berpengaruh terhadap fisik tapi juga psikis. Jika dilihat dari keseluruhan sistem anatomi, kesembilan sistem yang dikelompokkan berdasarkan struktur dan fungsinya menurut anatomi sistematik hendaknya berfungsi secara keseluruhan, walaupun hanya satu sistem yang tidak berfungsi dengan baik kerugian yang nyata dalam kesehatan mungkin saja akan dialami yang berdampak pada kesehatan fisik dan kesehatan psikis. Lebih mengkhusus ajaran āsana dapat berpengaruh terhadap berfungsinya anatomi sistematik sebagai berikut :

\section{a. Peran āsana dalam Artikulasio}

Assana yang berperan dalam kesehatan sistem lokomotorik salah satunya yaitu persendian adalah Pavanamuktāsana yang merupakan salah satu dari kelompok pemula ajaran āsana. Pavana berarti 'angin' mukta berarti 'membebaskan' dan āsana berarti 'sikap badan', oleh karena itu Pavanamuktāsana adalah sekelompok latihan yang membebaskan angin dan gas dari tubuh (Sarasvatī, 2002: 19).

Sebagai bagian dari kelompok pemula dari ajaran āsana, pelaksanaan latihan ini tergolong mudah untuk dilaksanakan, namun memiliki manfaat yang besar bagi tubuh terutamanya yang berkaitan dengan pengobatan oriental yang dimiliki agama Hindu tentang Ayurveda yaitu tiga sumber utama penyakit dalam diri manusia sebagai kekacauan dari keseimbangan tiga dosha yaitu vâta/vayu, pitta, dan kapha. Secara kasar, mereka dapat diwakilkan dengan istilah, angin untuk vātal vayu, air empedu untuk pitta, dan lendir untuk kapha (Dash dan Ramaswamy, 2006: 5). Menurut Âyurveda penyakit akibat kuman merupakan factor kedua, factor yang utama adalah factor dosha yang ada dalam tubuh manusia itu sendiri. Ketiga unsur tersebut harus seimbang secara simultan. Salah satu unsur saja tidak berfungsi secara optimal maka menimbulkan reaksi negative pada metabolisme tubuh sehingga menghasilkan suatu penyakit. Demikian juga unsur angin (vāta) dan asam serta air empedu (pitta).

Unsur angin dalam tubuh tidak hanya mengenai gas-gas yang ada pada lambung perut ataupun pada usus, namun juga gas pada setiap persendian yang dibentuk pada seluruh tubuh. Misalkan seperti karena reaksi-reaksi kimiawi yang tidak tepat alhasil menghasilkan kekakuan pada persendian hingga terjadinya penyakit rematik.

Sendi atau artikulasio adalah istilah yang digunakan untuk menunjukan pertemuan antara dua atau beberapa tulang kerangka. Terdapat tiga jenis sendi utama yaitu; sendi yang fibrus, sendi tulang rawan, dan sendi synovial, sendi juga dapat diklasifikasikan menurut kemungkinan geraknya ; tak bergerak, sedikit bergerak, dan bergerak luas (Pearce, 2017:104).

Gas pada setiap persendian akibat kimiawi yang kurang tepat hendaknya dikeluarkan dari tubuh. Mengeluarkan asam dan angin yang berlebih dari tubuh bisa dilakukan dengan latihan-latihan āsana yaitu salah satunya dengan Pavanamuktāsana. Asam dan air empedu mengacu pada getah-getah yang penting untuk pencernaan dan zat seperti asam uric yang harus dikeluarkan dari tubuh secara teratur, jika ada asam yang berlebihan pada jaringan tersebut maka kegagalan fungsi pada organ-organ tertentu akan terjadi. Latihan Pavanamuktāsana akan membantu mengeluarkan angin dan asam yang berklebihan dari tubuh terutama dari persendian. Latihan-latihan tersebut berguna bagi orang-orang yang sedang dalam masa penyembuhan, orangorang cacat dan orang-orang yang mempunyai kesulitan menggerakkan anggota badan mereka, setelah berbaring lama ditempat tidur seseorang dapat melatih kembali otot-ototnya dengan lembut melalui latihan-latihan ini. Latihan ini juga efektif dalam menghilangkan penyakit otot (Sarasvatī, 2002: 19).

Latihan ini dibagi menjadi dua kelompok yaitu kelompok anti rematik, dan kelompok anti lambung yang mengajarkan gerakan-gerakan masing-masing sesuai dengan urutan yang dipaparkan pada naskah yang tidak memungkinkan untuk dibahas secara detil pada tulisan ini. 


\section{b. Peran āsana dalam Pektroalis Mayor}

Peranan āsana yang kedua dalam anatomi sistematik adalah bagian otot tepatnya otot yang dinamai menurut fungsinya. Otot dikaitkan pada tulang, tulang rawan, ligament, dan kulit. Yang langsung terletak dibawah kulit adalah datar, dan yang pada anggota gerak adalah panjang. Otot kerangka ada kalanya dinamai menurut bentuknya, seperti Deltoid; menurut jurusan serabutnya, Rektus abdominis; menurut kedudukan otot, Pektoralis Mayor; menurut fungsinya, seperti fleksor, Ekstensor, dan sebagainya (Pearce, 2017: 122).

Latihan Pavanamuktāsana untuk persendian diatas juga dapat digunakan sebagai peregangan otot-otot, disamping itu terdapat salah satu gerakan āsana, Aśva Sañcalanāsana yang merupakan bagian dari gerakan Suryā Namaskāra, memberikan manfaat yang hampir tak terhingga, hal ini tidak dapat dihubungkan dengan satu posisi saja tetapi merupakan hasil dari seluruh latihan. Suryā Namaskāra memiliki manfaat yang yang sangat kuat pada semua jaringan tubuh: kelenjar endoktrin, peredaran darah, pernafasan, pencernaan, dan lain-lain serta membantu membuat semuanya menjadi saling seimbang dengan yang lainnya (Sarasvatī, 2002: 147). Salah satu bentuk gerakan dari Suryā Namaskāra adalah Aśva Sañcalanāsana yang bermanfaat untuk memijat organ-organ perut dan memperbaiki fungsinya, otot-otot kaki akan diperkuat, keseimbangan urat saraf akan tercapai (Sarasvatī, 2002: 142). Adapun gerakannya sebagai berikut :

Aśva Sañcalanāsana

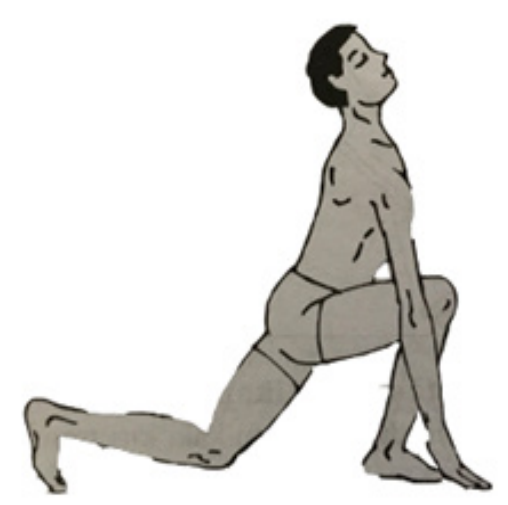

Sumber foto : Sarasvatī, 2002: 137.
Selain gerakan tersebut diatas, terdapat gerakan Parvatāsana, yang bermanfaat untuk otot, yaitu untuk menguatkan syaraf dan otot-otot pada kedua lengan dan kaki, melenturkan tulang belakang pada arah yang berlawanan menuju sikap sebelumnya dan lebih jauh membantu membuatnya lemas, menyelaraskan urat syaraf, tulang belakang, dan memberikan syaraf-syaraf tersebut aliran darah yang segar (Sarasvatī, 2002: 138). Adapun gerakannya sebagai berikut :

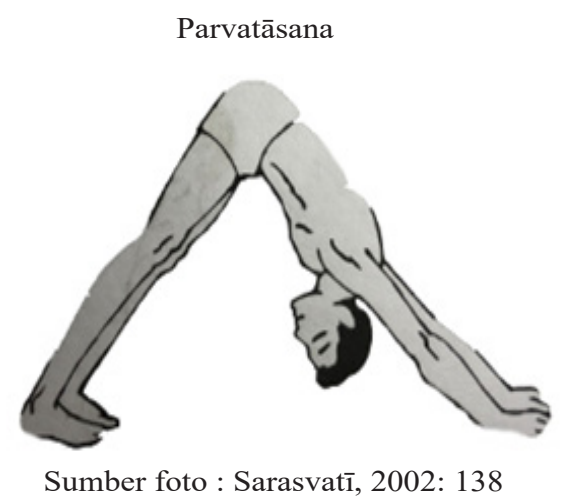

\section{c. Peran àsana dalam Kolumna Vertebralis}

Kolumna Vertebralis atau rangkaian tulang belakang adalah struktur lentur sejumlah tulang yang disebut vertebra atau ruas tulang belakang. Antara tiap dua ruas tulang pada tulang belakang terdapat bantalan tulang rawan. Vertebra dikelompokkan dan dinamai sesuai dengan daerah yang ditempatinya menurut Pearce (2017: 66), yaitu :

- Tujuh vertebra servikal atau ruas tulang leher membentuk daerah tengkuk

- Dua belas vertebra torakalis atau ruas tulang punggung membentuk bagian belakang toraks atau dada

- Lima vertebra lumbalis atau ruas tulan pinggang membentuk daerah lumbal atau pinggang

- Lima vertebra sakralis atau ruas tulang kelangkang membentuk sacrum atau tulang kelangkang

- Empat vertebra koksigeus atau ruas tulang tungging membentuk tulang koksigeus atau tulang tungging 
Lengkung-lengkung tulang belakang

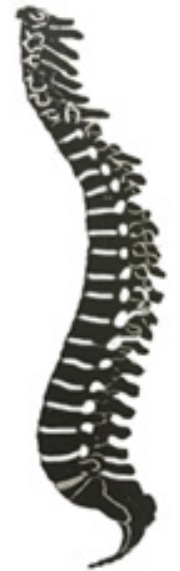

Sumber foto: Pearche, 2017: 73.

Salah satu gerakan āsana yang bermanfaat untuk tulang belakang adalah Kandharāsana. Latihan gerakan ini bermanfaat untuk mengembalikan lapisan tulang rawan dari tulang belakang yang salah, āsana ini juga meregangkan dan memijat usus besar dan organ tubuh lainnya, meluruskan bahu, yang tegap dan menghilangkan sakit punggung, adapun latihannya digambarkan sebagai berikut :

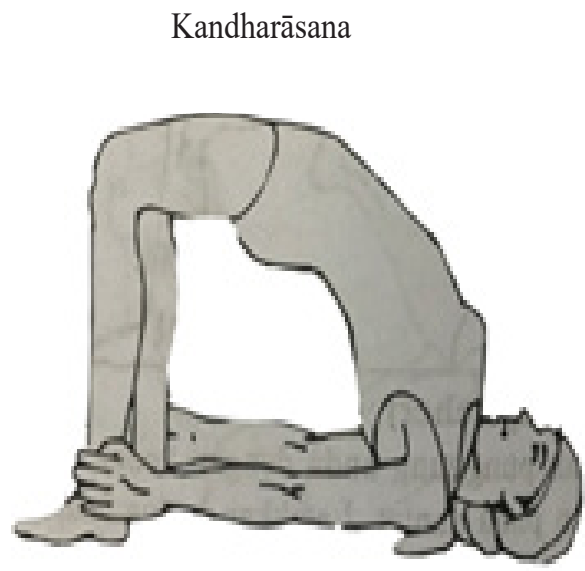

Sumber foto : Sarasvatī, 2002: 180.

Tidak hanya gerakan-gerakan āsana diatas, namun masih banyak dan semua gerakan yang ada pada āsana sangat bermanfaat untuk otot dan berfungsinya secara optimal anatomi sistematik lainnya pada tubuh manusia. Hanya dari salah satu latihan gerakan secara keseluruhan saja mampu bermanfaat untuk beberapa sistem anatomi sistematik sekaligus. Salah satunya manfaat yang tak terhingga dari melaksanakan latihan-latihan gerakan Suryā Namaskāra secara keseluruhan, yang tidak hanya saja bermanfaat untuk otot, tapi juga untuk kelenjar endoktrin, peredaran darah, pernafasan, pencernaan, serta sistem yang lainnya dalam anatomi sistematik sehingga dapat menjadi berfungsi optimal dan saling seimbang. Tentunya dengan berfungsinya secara seimbang dan optimal anatomi sistematik, akan menghasilkan kesehatan baik fisik ataupun psikis yang saling berhubungan dan mempengaruhi, sehingga terwujudlah kesehatan se-utuhnya.

\section{PENUTUP}

Melalui pembahasan diatas dapat disimpulkan bahwa kebutuhan manusia akan kesehatan fisik dan psikis dapat diperoleh salah satunya melalui cara yang oriental yang dimilki dalam agama Hindu yaitu āsana. Sesuai dengan teori fungsionalisme structural dari Merton, berkaitan dengan pembahasan disini, teori tersebut bisa digunakan ideologinya, sehingga bisa diketahui bahwa āsana sebagai salah satu bagian dari kelompok prinsip ajaran yoga memiliki fungsi yang dapat diamati, fungsi tersebut tidak lain adalah melalui āsana kesehatan fisik dan mental/ psikis dapat diperoleh seseorang dengan cara melatih gerakangerakan yang ada dalam naskah ajaran āsana, salah satunya gerakan Suryā Namaskāra yang memberikan manfaat yang hampir tak terhingga, yang mana tidak dapat dihubungkan dengan satu posisi tetapi merupakan hasil dari seluruh latihan. Suryā Namaskāra memiliki manfaat yang yang sangat kuat pada semua jaringan tubuh: kelenjar endoktrin, peredaran darah, pernafasan, pencernaan, dan lain-lain serta membantu membuat semuanya menjadi saling seimbang dengan yang lainnya sehingga terwujudlah satu kesatuan kesehatan tubuh manusia itu sendiri yaitu kesehatan psikis dan kesehatan fisik yang saling mempengaruhi dan berhubungan.

\section{DAFTAR PUSTAKA}

Dash, Vaidya Bhagawan dan Sushasini Ramaswamy, 2006. Ayur Vedallmu Pengobatan Tradisional India. Surabaya: Pāramita.

Donder, I Ketut, 2006. Brahmawidyā Teologi Kasih Semesta dan Kritik Terhadap Epistemologi 
Teologi, Klamim Kebenaran, Program Misi, Komparasi Teologi, dan Konversi. Surabaya: Pāramita.

Gunawan, I Ketut Pasek, 2012. Filsafat Hindu Nawa Darsana Ajaran Pañca Śraddha Menemukan Kebenaran. Surabaha: Pāramita.

Mirsha, I Gusti Ngurah Rai, dkk, 1994. Wrhaspati Tattwa, Ganapati Tattwa, Tattwa Jnana Kajian Teks dan Terjemahannya. UPD. Kantor Dokumentasi Budaya Bali Provinsi Daerah Tingkat Bali.

Pals, Daniel L, 2012. Seven Theories of Religion. Jogjakarta: IRCiSoD.

Pearce, Evelyn C, 2017. Anatomi dan Fisiologi Untuk Paramedis. Jakarta: Gramedia Pustaka Utama.

Pendit, Nyoman S, 2007. Filsafat Hindu Dharma Sad-Darsana Enam Aliran Astika (Ortodoks). Denpasar: Pustaka Bali Post.

Ritzer, George, 2015. Teori Sosiologi Modern, Jakarta: Prenadamedia Group.

Sarasvatī, Svāmi Satyānanda, 2002. Āsana, Prāṇāyāma, Mudrā, Bandha. Surabaya: Pāramita. 